\title{
Mineral formation in stellar winds
}

\section{Formation of magnesiowüstite}

\begin{abstract}
A. S. Ferrarotti and H.-P. Gail
Institut für Theoretische Astrophysik, Universität Heidelberg, Tiergartenstraße 15, 69121 Heidelberg, Germany

Received 2 August 2002 / Accepted 7 November 2002

Abstract. The possible formation of iron-magnesium-oxides in stellar outflows from cool stars with oxygen rich element mixture is discussed. Chemical equilibrium calculations for the non-ideal solid solution magnesiowüstite with composition $\mathrm{Mg}_{x} \mathrm{Fe}_{1-x-\delta} \mathrm{O}$ show that this oxide may be formed under conditions of imperfect equilibrium condensation. A model is developed for calculating the condensation of magnesiowüstite under non equilibrium conditions in stellar outflows and numerical models for multi-component dust condensation including magnesiowüstite in oxygen rich stellar outflows from cool stars are calculated. It is found that magnesiowüstite should be formed in small but probably detectable quantities in outflows from oxygen rich AGB-stars with mass-loss rates $\dot{M} \lesssim 4 \times 10^{-6} M_{\odot} \mathrm{yr}^{-1}$. It forms a feature in the spectrum which seems to correspond to a not yet identified feature seen in some circumstellar dust shells. For higher mass-loss rates condensation of magnesiowüstite is suppressed by early massive condensation of silicates.
\end{abstract}

Key words. circumstellar matter - dust, extinction - stars: mass-loss - stars: winds, outflows - stars: AGB and post-AGB

\section{Introduction}

During the last stages of their evolution most stars become efficient dust factories. Low and intermediate mass stars (initial mass $M_{*} \lesssim 8 M_{\odot}$ ) loose most of their initial mass in a massive stellar wind as giant stars on the AGB and develop optically very thick dust shells around them. Massive stars with initial masses $M \lesssim 25 M_{\odot}$ reach the RGB stage before they explode as a supernova. They loose during their evolution as supergiants on the RGB a substantial fraction of their mass by a massive cool stellar wind and develop optically very thick dust shells, after having experienced already significant mass-loss without dust formation by a hot stellar wind during their preceding evolution as $\mathrm{O}$ or B stars.

The element mixture in stellar winds of AGB stars either is oxygen rich ( $\mathrm{M}$ stars) or carbon rich ( $\mathrm{C}$ stars) and in a small number of cases $\mathrm{C}$ and $\mathrm{O}$ have almost equal abundances ( $\mathrm{S}$ stars). For RGB stars the element mixture is always oxygen rich. Depending on the carbon to oxygen abundance ratio, the dust mixture formed in the outflows from cool giant stars is quite different.

It is known since the very first detection of circumstellar dust shells by their infrared emission at the end of the 60's that for stars with an oxygen rich element mixture in their stellar atmosphere, the dominating dust component in their outflow is an amorphous $\mathrm{Mg}$-Fe silicate. The amorphous silicate is identified by its two broad featureless emission or absorption bands

Send offprint requests to: H.-P. Gail, e-mail: gail@ita.uni-heidelberg.de centred on about $9.7 \mu \mathrm{m}$ and $18 \mu \mathrm{m}$. Infrared spectroscopy in the late 80's already gave first evidence that the composition of the dust in circumstellar shells around oxygen rich objects is more complex. Indications of structure in the silicate bands (Aitken et al. 1988) and indications for additional weak emission bands pointing to the presence of non-silicatic dust components (e.g. Onaka et al. 1989) where found. The drastically improved resolution of IR spectroscopy and the extension of the spectroscopy into the far IR by the ISO satellite finally revealed a much more complex composition of the dust in oxygen rich circumstellar shells than previously thought (Waters et al. 1996).

A rich forest of solid state emission bands in the spectral region $\lambda>20 \mu \mathrm{m}$ clearly shows that in many objects part of the dust has a crystalline structure and consists of a mixture of Fe-poor olivine and orthopyroxene (e.g. Molster et al. 2002a, 2002b, 2002c). Additional dust components have been identified by the presence of some of their extinction bands or are speculated to exist since some not yet identified emission features in the spectra could be explained by the presence of such dust species (e.g. Molster 2000; Molster et al. 2002a).

One such not yet clearly identified structure in the infrared spectra of some objects is a rather broad emission feature centred on about $20 \mu \mathrm{m}$ (Molster et al. 1999). It has been proposed that this feature is due to iron oxide $\mathrm{FeO}$ (Henning et al. 1995; Posch et al. 2002) since $\mathrm{FeO}$ or its solid solution with $\mathrm{MgO}$ has a broad emission band at just the right wavelength region and since Fe has sufficient abundance to form an abundant oxide dust component. Iron oxides as components of 
circumstellar dust have also been proposed by Rietmeijer (1992). Henning et al. (1995) determined the optical constants of magnesiowüstite.

In this paper we study the condensation of the oxides of Fe and $\mathrm{Mg}$ and of the solid solution $\mathrm{Mg}_{x} \mathrm{Fe}_{1-x-\delta} \mathrm{O}$, called magnesiowüstite, from a theoretical point of view. We first perform some chemical equilibrium calculations in order to determine the stability of $\mathrm{Fe}$ and $\mathrm{Mg}$ oxides in the element mixtures outflowing from AGB giants and RGB supergiants with an oxygen rich element mixture. These calculations show magnesiowüstite to be a likely condensate. Then a model is developed for the non-equilibrium condensation of magnesiowüstite in a cool stellar outflow and a set of models is calculated which demonstrate magnesiowüstite to be also a likely candidate for condensation under non-equilibrium conditions.

\section{Condensation of $\mathrm{Fe}-\mathrm{Mg}$ oxides}

First we consider the condensation of the oxides of $\mathrm{Mg}$ and Fe in chemical equilibrium. Clearly, in a stellar outflow the condensation of solids from the cooling and expanding gas is a non-equilibrium process. Chemical equilibrium is, however, well suited to determine which condensates are stable against evaporation or decomposition in a given environment. This helps to find out which of the possible condensates could be stable in a stellar outflow and, thus, have to be considered as candidate dust material in non-equilibrium condensation calculations.

\subsection{Oxides of $\mathrm{Mg}$ and $\mathrm{Fe}$}

$\mathrm{Mg}$ forms only one oxide, $\mathrm{MgO}$, which is stable up to high temperatures. Fe forms three oxides:

- wüstite with composition $\mathrm{Fe}_{1-\delta} \mathrm{O}$. In this compound the $\mathrm{Fe}$ atoms are twofold positively charged ions. At a small fraction of the cation sites, however, the $\mathrm{Fe}^{2+}$ cations are replaced by $\mathrm{Fe}^{3+}$ cations and for any two $\mathrm{Fe}^{3+}$ cations there is one vacancy at some cation site for reasons of charge neutrality.

- Hematite with composition $\mathrm{Fe}_{2} \mathrm{O}_{3}$. Only $\mathrm{Fe}^{3+}$ cations form this compound.

- Magnetite with composition $\mathrm{Fe}_{3} \mathrm{O}_{4}$.

Additionally there exist two solid solutions between magnesium and iron oxides:

- The solid solution series between $\mathrm{Fe}_{1-\delta} \mathrm{O}$ and $\mathrm{MgO}$ called magnesiowüstite.

- The solid solution series with the end members $\mathrm{Fe}_{3} \mathrm{O}_{4}$ $\left(=\mathrm{FeO} \cdot \mathrm{Fe}_{2} \mathrm{O}_{3}\right)$ and $\mathrm{MgFe}_{2} \mathrm{O}_{4}\left(=\mathrm{MgO} \cdot \mathrm{Fe}_{2} \mathrm{O}_{3}\right)$.

From these $\mathrm{Mg}$ and $\mathrm{Fe}$ oxides only hematite and magnetite are chemically stable in the cosmic standard element mixture at low pressure. Their upper stability limits occur at a rather low temperature (cf. Fig. 1) and it is unlikely (though not impossible) that they can form in a stellar outflow, because the formation of magnesiowüstite under non-equilibrium conditions already is not particular efficient (see Sect. 4.3) and the

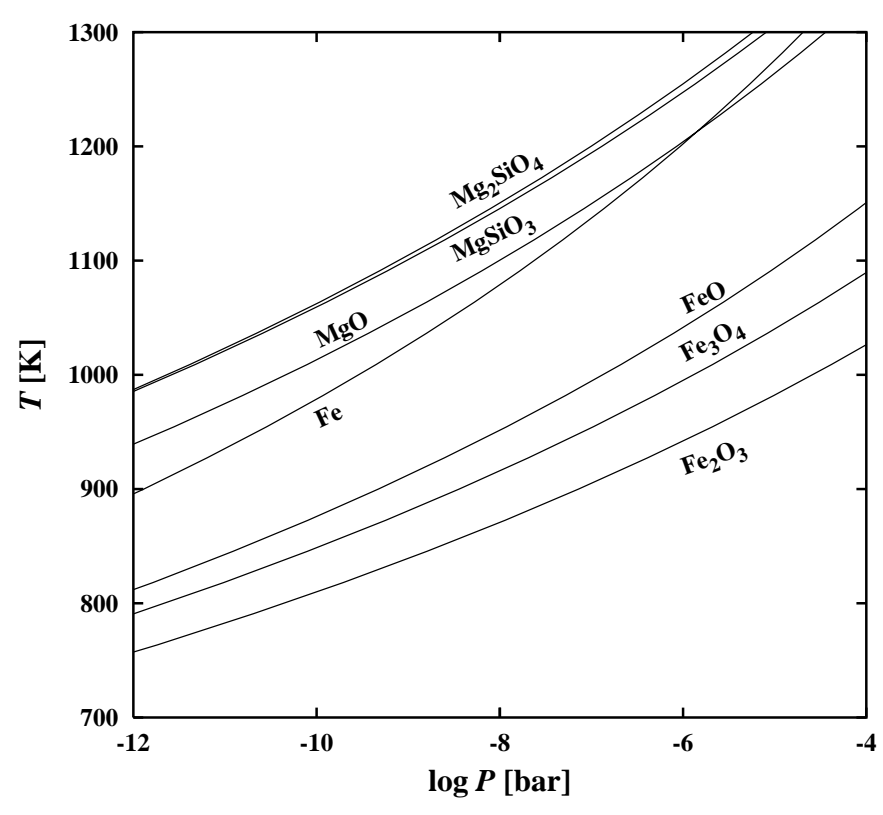

Fig. 1. Stability limits of the oxides of $\mathrm{Mg}$ and $\mathrm{Fe}$ for direct condensation from the gas phase. In each case it is assumed that no other solids are present at the same time. For comparison the stability limits of the silicates and of solid iron (calculated for chemical equilibrium) also are shown.

formation conditions for further dust components under nonequilibrium conditions in a stellar outflow become increasingly unfavourable with decreasing temperature.

In chemical equilibrium between all components the quite stable $\mathrm{MgO}$ does not exist because the $\mathrm{Mg}$ is completely consumed by the formation of the more stable Fe-Mg-silicates. In a stellar wind, however, the process of dust formation of the silicates does not run into completion until the gas has cooled below the stability limit of $\mathrm{MgO}$ and a significant fraction of the $\mathrm{Mg}$ is left over in the gas phase at this instant to form $\mathrm{MgO}$. Our previous model calculations (Gail \& Sedlmayr 1999; Ferrarotti $\&$ Gail 2001) have already shown that because of the nonequilibrium nature of condensation in stellar outflows a certain quantity of solid $\mathrm{MgO}$ should be formed. Since the $\mathrm{MgO}$ forms a solid solution with $\mathrm{FeO}$ it is more likely, however, that in the presence of $\mathrm{Fe}$ vapour in the gas phase magnesiowüstite $\mathrm{Mg}_{x} \mathrm{Fe}_{1-x-\delta}$ is formed in the outflow and not pure $\mathrm{MgO}$.

We determine the individual stability limits of the pure $\mathrm{Mg}$ and Fe oxides for the case that no other solids are present. This corresponds, for instance, to the case where cooling is so rapid that only incomplete condensation occurs and much of the condensible material is left in the gas phase which in case of chemical equilibrium would already have been consumed by the formation of the most stable condensates. The possible chemical reactions are

$$
\begin{aligned}
& \mathrm{Mg}+\mathrm{H}_{2} \mathrm{O} \longrightarrow \mathrm{MgO}(\mathrm{s})+\mathrm{H}_{2} \\
& \mathrm{Fe}+\mathrm{H}_{2} \mathrm{O} \longrightarrow \mathrm{FeO}(\mathrm{s})+\mathrm{H}_{2} \\
& 2 \mathrm{Fe}+3 \mathrm{H}_{2} \mathrm{O} \longrightarrow \mathrm{Fe}_{2} \mathrm{O}_{3}(\mathrm{~s})+3 \mathrm{H}_{2} \\
& 3 \mathrm{Fe}+4 \mathrm{H}_{2} \mathrm{O} \longrightarrow \mathrm{Fe}_{3} \mathrm{O}_{4}(\mathrm{~s})+4 \mathrm{H}_{2}
\end{aligned}
$$


For comparison we also calculate the stability limits of forsterite, enstatite and solid iron in chemical equilibrium

$$
\begin{aligned}
& 2 \mathrm{Mg}+\mathrm{Si}+4 \mathrm{H}_{2} \mathrm{O} \longrightarrow \mathrm{Mg}_{2} \mathrm{SiO}_{4}(\mathrm{~s})+4 \mathrm{H}_{2} \\
& \mathrm{Mg}+\mathrm{Si}+3 \mathrm{H}_{2} \mathrm{O} \longrightarrow \mathrm{MgSiO}_{3}(\mathrm{~s})+3 \mathrm{H}_{2} \\
& \mathrm{Fe} \longrightarrow \mathrm{Fe}(\mathrm{s})
\end{aligned}
$$

The calculation of the stability limits is done as in Gail (1998a). The results are shown in Fig. 1.

In the pressure regime around $P \approx 10^{-10}$ bar, typical for the condensation zone in circumstellar shells, the stability limit of $\mathrm{MgO}$ occurs at a temperature somewhat lower than the stability limits of the silicates, but lower by only about $50 \mathrm{~K}$, and it occurs at a temperature about $30 \mathrm{~K}$ above the stability limit of solid iron. The stability limit of solid $\mathrm{FeO}$, on the other hand, occurs at a temperature about $150 \mathrm{~K}$ below that of $\mathrm{MgO}$. Since the growth of dust in stellar outflows extends over a much wider temperature interval than this, the growth process of the silicates and of solid iron in a rapidly cooling wind is not completed until the gas has cooled down first below the stability limit of $\mathrm{MgO}$ and next below the stability limit of $\mathrm{FeO}$.

This shows: $\mathrm{MgO}$ condensation becomes possible soon after the onset of silicate condensation and prior to the formation of solid iron and the $\mathrm{MgO}$ starts to take up considerable amounts of $\mathrm{Fe}$ if the temperature drops below the stability limit of $\mathrm{FeO}$.

Even a further oxidation of the magnesiowüstite to magnetite seems not to be excluded, as the close proximity of the $\mathrm{FeO}$ to the $\mathrm{Fe}_{3} \mathrm{O}_{4}$ stability limit and the laboratory experiments of Riemeijer et al. (1999a, 1999b) suggest. No experimental data for calculating the kinetics of the further oxidation processes seem to be available, however, and for this reason we restrict our calculations to the formation of magnesiowüstite.

\subsection{The solid solution magnesiowüstite}

The magnesiowüstite can be conceived as a solid solution formed from the solids $\mathrm{FeO}, \mathrm{Fe}_{2} \mathrm{O}_{3}$ and $\mathrm{MgO}$ (Srečec et al. 1987). The $\mathrm{Fe}_{2} \mathrm{O}_{3}$ component accounts for the lattice vacancies in wüstite.

\subsubsection{Chemical equilibrium}

The solution components of magnesiowüstite can be formed from the gas phase by the following set of reactions

$$
\begin{aligned}
& \mathrm{Fe}+\mathrm{H}_{2} \mathrm{O} \rightarrow \mathrm{FeO}(\mathrm{mw})+\mathrm{H}_{2} \\
& \mathrm{Mg}+\mathrm{H}_{2} \mathrm{O} \rightarrow \mathrm{MgO}(\mathrm{mw})+\mathrm{H}_{2} \\
& 2 \mathrm{Fe}+3 \mathrm{H}_{2} \mathrm{O} \rightarrow \mathrm{Fe}_{2} \mathrm{O}_{3}(\mathrm{mw})+3 \mathrm{H}_{2}
\end{aligned}
$$

where "mw" indicates that the solid is formed as a component of magnesiowüstite.

None of these solution components would be formed in a state of complete chemical equilibrium. $\mathrm{Mg}$ and $\mathrm{Fe}$ would be completely consumed by the formation of silicates and of solid iron in that case. We consider, instead, the problem of formation of magnesiowüstite from the gas phase in the case where the formation of silicates and of solid iron are hindered, for instance by rapid cooling, but magnesiowüstite is in chemical equilibrium with the gas phase. The equilibrium conditions for the formation of the solid solution components are

$$
\begin{aligned}
& \mu\left(\mathrm{H}_{2} \mathrm{O}\right)+\mu(\mathrm{Fe})=\mu(\mathrm{FeO}, \mathrm{mw})+\mu\left(\mathrm{H}_{2}\right) \\
& \mu\left(\mathrm{H}_{2} \mathrm{O}\right)+\mu(\mathrm{Mg})=\mu(\mathrm{MgO}, \mathrm{mw})+\mu\left(\mathrm{H}_{2}\right) \\
& 3 \mu\left(\mathrm{H}_{2} \mathrm{O}\right)+2 \mu(\mathrm{Fe})=\mu\left(\mathrm{Fe}_{2} \mathrm{O}_{3}, \mathrm{mw}\right)+3 \mu\left(\mathrm{H}_{2}\right) .
\end{aligned}
$$

The chemical potentials $\mu$ of the individual species involved in the magnesiowüstite formation are given by:

$$
\begin{aligned}
& \mu\left(\mathrm{H}_{2} \mathrm{O}\right)=\Delta G(T)_{\mathrm{H}_{2} \mathrm{O}}+R T \ln \frac{p_{\mathrm{H}_{2} \mathrm{O}}}{p_{0}} \\
& \mu\left(\mathrm{H}_{2}\right)=\Delta G(T)_{\mathrm{H}_{2}}+R T \ln \frac{p_{\mathrm{H}_{2}}}{p_{0}} \\
& \mu(\mathrm{Fe})=\Delta G(T)_{\mathrm{Fe}}+R T \ln \frac{p_{\mathrm{Fe}}}{p_{0}} \\
& \mu(\mathrm{Mg})=\Delta G(T)_{\mathrm{Mg}}+R T \ln \frac{p_{\mathrm{Mg}}}{p_{0}}
\end{aligned}
$$

for the gaseous species, where $p_{0}$ is the standard pressure (=1 bar). For the solid species the chemical potentials are

$$
\begin{aligned}
& \mu(\mathrm{FeO})=\Delta G(T)_{\mathrm{FeO}}+R T \ln x_{\mathrm{FeO}}+R T \ln \gamma_{\mathrm{FeO}} \\
& \mu(\mathrm{MgO})=\Delta G(T)_{\mathrm{MgO}}+R T \ln x_{\mathrm{MgO}}+R T \ln \gamma_{\mathrm{MgO}} \\
& \mu\left(\mathrm{Fe}_{2} \mathrm{O}_{3}\right)=\Delta G(T)_{\mathrm{Fe}_{2} \mathrm{O}_{3}}+R T \ln x_{\mathrm{Fe}_{2} \mathrm{O}_{3}}+R T \ln \gamma_{\mathrm{Fe}_{2} \mathrm{O}_{3}}
\end{aligned}
$$

(Atkins 1994). The $x$ 's are the concentrations of the solution components and the $\gamma$ 's are their activity coefficients in the solution which describe the deviation from the ideal solution case. The $\Delta G$ 's are the changes of free enthalpy in the formation of the indicated species from the elements in their reference states.

Inserting Eqs. (11)-(17) into the thermodynamic equilibrium conditions (8)-(10) yields

$$
\begin{aligned}
\mathrm{e}^{\Delta G_{1} / R T} & =\frac{p_{\mathrm{H}_{2}} x_{\mathrm{FeO}} \gamma_{\mathrm{FeO}}}{p_{\mathrm{Fe}} p_{\mathrm{H}_{2} \mathrm{O}}} \\
\mathrm{e}^{\Delta G_{2} / R T} & =\frac{p_{\mathrm{H}_{2}} x_{\mathrm{MgO}} \gamma_{\mathrm{MgO}}}{p_{\mathrm{Mg}} p_{\mathrm{H}_{2} \mathrm{O}}} \\
\mathrm{e}^{\Delta G_{3} / R T} & =\frac{p_{\mathrm{H}_{2}}^{3} x_{\mathrm{Fe}_{2} \mathrm{O}_{3}} \gamma_{\mathrm{Fe}_{2} \mathrm{O}_{3}}}{p_{\mathrm{Fe}}^{2} p_{\mathrm{H}_{2} \mathrm{O}}^{3}}
\end{aligned}
$$

where

$$
\begin{aligned}
\Delta G_{1} & =\Delta G_{\mathrm{H}_{2} \mathrm{O}}-\Delta G_{\mathrm{FeO}(\mathrm{s})}-\Delta G_{\mathrm{H}_{2}} \\
\Delta G_{2} & =\Delta G_{\mathrm{H}_{2} \mathrm{O}}-\Delta G_{\mathrm{MgO}(\mathrm{s})}-\Delta G_{\mathrm{H}_{2}} \\
\Delta G_{3} & =3 \Delta G_{\mathrm{H}_{2} \mathrm{O}}+2 \Delta G_{\mathrm{Fe}}-\Delta G_{\mathrm{Fe}_{2} \mathrm{O}_{3}(\mathrm{~s})}-3 \Delta G_{\mathrm{H}_{2}} .
\end{aligned}
$$

The concentrations $x_{\mathrm{FeO}}, x_{\mathrm{MgO}}$ and $x_{\mathrm{Fe}_{2} \mathrm{O}_{3}}$ of the solution components are subject to the condition

$x_{\mathrm{FeO}}+x_{\mathrm{Fe}_{2} \mathrm{O}_{3}}+x_{\mathrm{MgO}}=1$.

The activity coefficients of the solution components of magnesiowüstite have been determined for instance by Srečec et al. (1987) at standard pressure $p_{0}$ and at temperatures between 1050 and $1400 \mathrm{~K}$. By fitting quadratic asymmetric Margules 

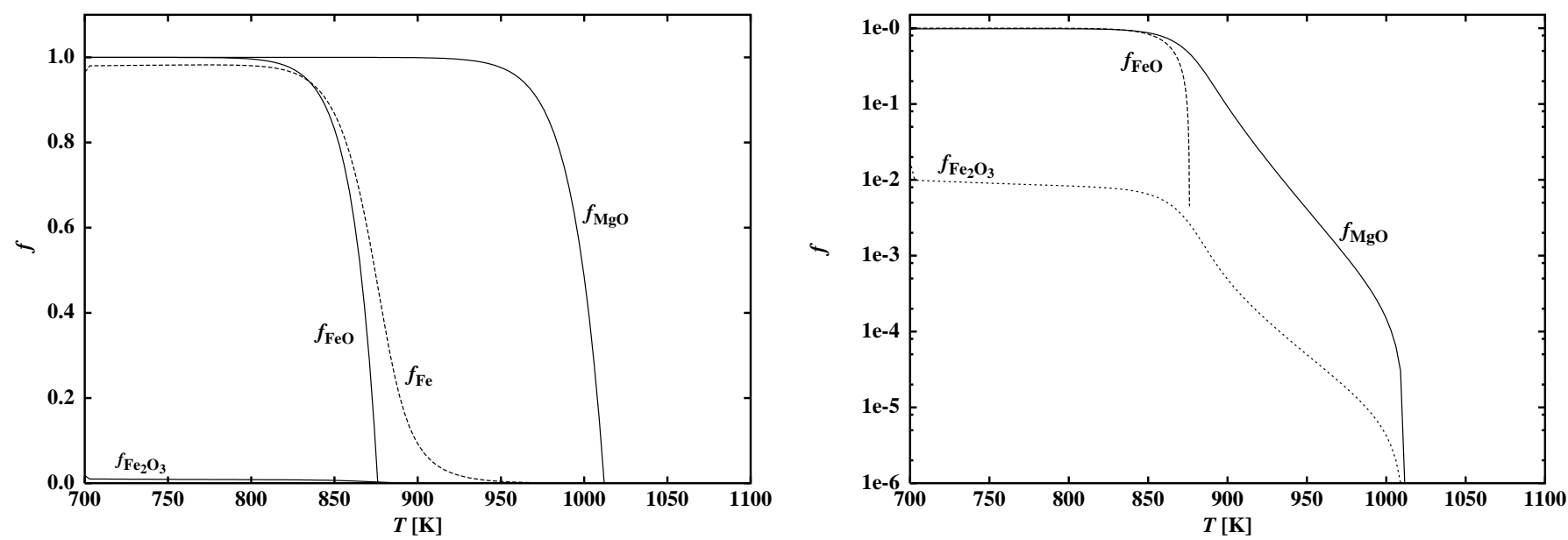

Fig. 2. Left part: Degree of condensation $f$ of $\mathrm{Fe}$ and $\mathrm{Mg}$ into magnesiowüstite for a range of temperatures and a total pressure of $P=10^{-10}$ bar. $f_{\mathrm{FeO}}$ and $f_{\mathrm{Fe}_{2} \mathrm{O}_{3}}$ are the fractions of the element $\mathrm{Fe}$ condensed into $\mathrm{FeO}$ and $\mathrm{Fe}_{2} \mathrm{O}_{3}$, respectively. $f_{\mathrm{MgO}}$ is the fraction of the element $\mathrm{Mg}$ condensed into $\mathrm{MgO}$. For comparison, the dashed line shows the degree of condensation of Fe in chemical equilibrium if solid iron would be the sole condensate. Right part: Logarithmic plot to show more clearly the $\mathrm{Fe}_{2} \mathrm{O}_{3}$ content of the solid solution.

equations (e.g. Philpotts 1990) to their experimental results they found

$$
\begin{aligned}
& \ln \gamma_{\mathrm{FeO}}=\left(\frac{521}{T}+5.062\right) x_{\mathrm{Fe}_{2} \mathrm{O}_{3}}^{2} \\
& +\left(-\frac{719}{T}+3.041\right) x_{\mathrm{Fe}_{2} \mathrm{O}_{3}} x_{\mathrm{MgO}}+\left(\frac{525}{T}+0.480\right) x_{\mathrm{MgO}}^{2} \\
& \ln \gamma_{\mathrm{Fe}_{2} \mathrm{O}_{3}}=\left(\frac{781}{T}-0.480\right) x_{\mathrm{FeO}}^{2} \\
& \quad+\left(\frac{698}{T}+2.582\right) x_{\mathrm{FeO}} x_{\mathrm{MgO}}+\left(\frac{1209}{T}+2.262\right) x_{\mathrm{MgO}^{2}}^{2} \\
& \ln \gamma_{\mathrm{MgO}}=\left(\frac{386}{T}+0.593\right) x_{\mathrm{FeO}}^{2} \\
& +\left(\frac{6211}{T}-3.587\right) x_{\mathrm{Fe}_{2} \mathrm{O}_{3}} x_{\mathrm{FeO}}+\left(-\frac{33630}{T}+36.210\right) x_{\mathrm{Fe}_{2} \mathrm{O}_{3}}^{2} \cdot
\end{aligned}
$$

In applying this to the formation of magnesiowüstite in circumstellar shells we need to apply the activity coefficients $\gamma$ considerably outside of the temperature regime for which they have been determined in the laboratory (cf. Fig. 1). It is not known, if this is admitted, but this is always a problem with such type of data, which cannot be measured at the low temperatures of interest in astrophysical problems.

\subsubsection{Constraints from element abundances}

Additional to the equations for chemical equilibrium we have the equations for the abundances of the elements involved in the formation of the solution components in magnesiowüstite. For our problem it suffices to assume that all hydrogen is bound in $\mathrm{H}_{2}$ molecules at the low temperatures of interest. In this case the fictitious partial pressure $P_{\mathrm{H}}$ of all hydrogen nuclei is given by

$P_{\mathrm{H}}=\frac{2 P}{1+2 \epsilon_{\mathrm{He}}}$
$P$ is the total pressure and $\epsilon_{\mathrm{He}}$ the element abundance of He (by number) relative to $\mathrm{H}$. The partial pressure of $\mathrm{H}_{2}$ is

$p_{\mathrm{H}_{2}}=\frac{1}{2} P_{\mathrm{H}}$.

Further we can safely assume that all carbon is bound in $\mathrm{CO}$ and can simply take this into account by reducing the oxygen abundance by the abundance of carbon.

We define a degree of condensation $f_{\mathrm{mw}}$ of material from the gas phase into magnesiowüstite by the fraction of the oxygen nuclei condensed into $\mathrm{Mg}_{x_{\mathrm{MgO}}} \mathrm{Fe}_{\left(x_{\mathrm{FeO}}+x_{\mathrm{Fe}_{2} \mathrm{O}_{3}}\right)} \mathrm{O}$. Then for each $\mathrm{O}$ atom in magnesiowüstite there are $x_{\mathrm{MgO}}$ atoms of $\mathrm{Mg}$ bound in the solution component $\mathrm{MgO}, x_{\mathrm{FeO}}$ atoms of Fe bound in the solution component $\mathrm{FeO}$, and $x_{\mathrm{Fe}_{2} \mathrm{O}_{3}} \mathrm{Fe}$ atoms bound in the solution component $\mathrm{Fe}_{2} \mathrm{O}_{3}$. The partial pressure of free $\mathrm{Fe}$ atoms in the gas phase then is given by

$p_{\mathrm{Fe}}=\epsilon_{\mathrm{Fe}} P_{\mathrm{H}}-\epsilon_{\mathrm{O}} f_{\mathrm{mw}} P_{\mathrm{H}}\left(x_{\mathrm{FeO}}+x_{\mathrm{Fe}_{2} \mathrm{O}_{3}}\right)$,

the partial pressure of free $\mathrm{Mg}$ atoms is given by

$p_{\mathrm{Mg}}=\epsilon_{\mathrm{Mg}} P_{\mathrm{H}}-\epsilon_{\mathrm{O}} f_{\mathrm{mw}} P_{\mathrm{H}} x_{\mathrm{MgO}}$,

and the partial pressure of water molecules by

$p_{\mathrm{H}_{2} \mathrm{O}}=\epsilon_{\mathrm{O}} P_{\mathrm{H}}-\epsilon_{\mathrm{C}} P_{\mathrm{H}}-\epsilon_{\mathrm{O}} f_{\mathrm{mw}} P_{\mathrm{H}}$.

\subsubsection{Results}

The set of Eqs. (18)-(20) and (30)-(32) and the condition (24) form a set of seven equations for the seven unknowns $x_{\mathrm{MgO}}$, $x_{\mathrm{FeO}}, x_{\mathrm{Fe}_{2} \mathrm{O}_{3}}, f_{\mathrm{mw}}$ and $p_{\mathrm{Mg}}, p_{\mathrm{Fe}}, p_{\mathrm{H}_{2} \mathrm{O}}$. The pressure $p_{\mathrm{H}_{2}}$ is given by (29). The free enthalpies of formation of the gaseous species and the solid solution components are taken from Sharp \& Huebner (1990). The non-linear set of equations was solved by Newton-Raphson iteration.

The left part of Fig. 2 shows for a total pressure of $P=$ $10^{-10}$ bar, typical for the condensation zone in circumstellar shells, the variation of the fraction $f_{\mathrm{MgO}}$ of the element $\mathrm{Mg}$ condensed into the solution component $\mathrm{MgO}$ of magnesiowüstite 


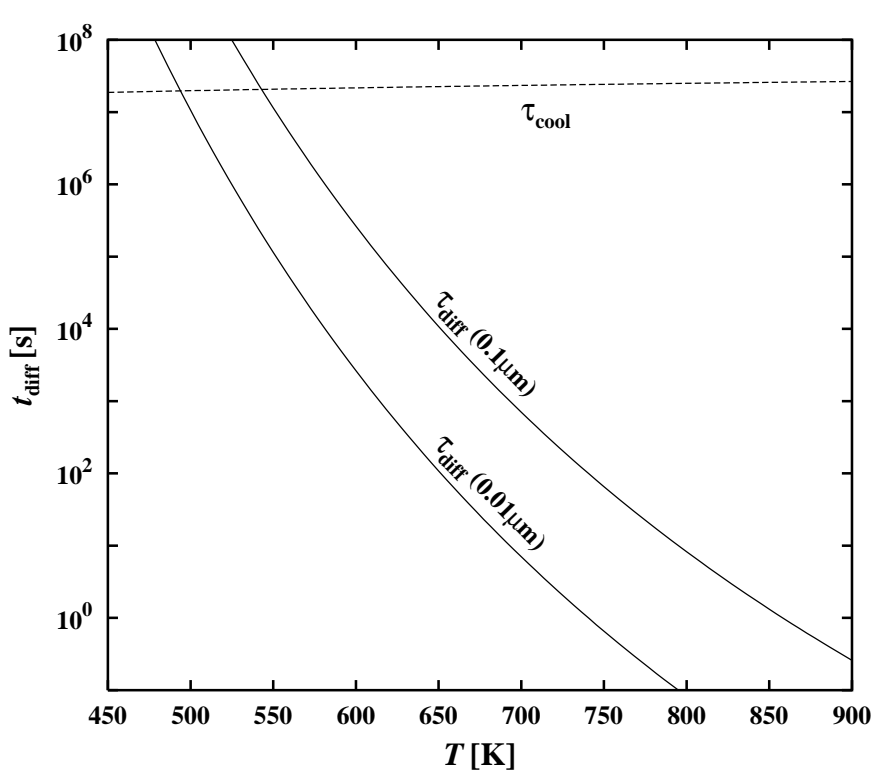

Fig. 3. Characteristic timescale $\tau_{\text {diff }}$ for homogenization of composition differences within magnesiowüstite grains of size $a=0.1 \mu \mathrm{m}$ and $0.01 \mu \mathrm{m}$ and characteristic cooling timescale $\tau_{\text {cool }}$ of the outflowing gas (dashed line).

and the fractions $f_{\mathrm{FeO}}$ and $f_{\mathrm{Fe}_{2} \mathrm{O}_{3}}$ of the element Fe condensed into the solution components $\mathrm{FeO}$ and $\mathrm{Fe}_{2} \mathrm{O}_{3}$ of the magnesiowüstite. These are related to the concentrations by

$f_{\mathrm{MgO}}=\frac{x_{\mathrm{MgO}} f_{\mathrm{mw}} \epsilon_{\mathrm{O}}}{\epsilon_{\mathrm{Mg}}}$

$f_{\mathrm{FeO}}=\frac{x_{\mathrm{FeO}} f_{\mathrm{mw}} \epsilon_{\mathrm{O}}}{\epsilon_{\mathrm{Fe}}}$

$f_{\mathrm{Fe}_{2} \mathrm{O}_{3}}=\frac{x_{\mathrm{Fe}_{2} \mathrm{O}_{3}} f_{\mathrm{mw}} \epsilon_{\mathrm{O}}}{\epsilon_{\mathrm{Fe}}}$.

The figure shows for comparison as dashed line the fraction of Fe condensed into solid iron, if only iron would condense from the gas phase and no other solid compound.

The right part of Fig. 2 shows for the same pressure $P$ the fractions $f_{\mathrm{MgO}}, f_{\mathrm{FeO}}$, and $f_{\mathrm{Fe}_{2} \mathrm{O}_{3}}$ in a plot with a logarithmic scale in order to show more clearly the fraction of $\mathrm{Fe}_{2} \mathrm{O}_{3}$ contained in magnesiowüstite. With about $1 \% \mathrm{Fe}^{3+}$ cations over much of the temperature region where magnesiowüstite has a significant Fe content, the vacancy content of magnesiowüstite in the circumstellar dust shell is markedly lower than under terrestrial conditions $(3-4 \%)$.

\subsection{Diffusion in Wüstite}

The condensation of magnesiowüstite in chemical equilibrium starts at the stability limit of pure $\mathrm{MgO}$ as essentially pure $\mathrm{MgO}$ particles. Only if the temperature has dropped close to the stability limit of $\mathrm{FeO}$ a solid solution with considerable $\mathrm{Fe}$ content would be formed. This rises the following question: If a particle in a stellar outflow first grows as magnesium oxide grain and later tends to add additional layers of magnesiowüstite, what happens to the $\mathrm{MgO}$ core? It can equilibrate in composition with the outer layers only by diffusion of $\mathrm{Mg}^{2+}$ and $\mathrm{Fe}^{2+}$ cations through the lattice. If the diffusion timescale of the cations across a grain is short compared to the characteristic timescale for grain growth, then the particles are compositionally homogeneous. Also the initial $\mathrm{MgO}$ core later adjust its composition to that of the outer magnesiowüstite layers by cation diffusion. In the opposite case the particles develop a core-mantle structure with a pure $\mathrm{MgO}$ core and a magnesiowüstite mantle.

We have not succeeded to find experimental values for cation diffusion in magnesiowüstite. Diffusion in pure wüstite, however, has been experimentally determined. Rickert \& Weppner (1974) measured cation diffusion in wüstite of composition $\mathrm{Fe}_{1-\delta}$ in the range $\delta=0.060-0.15$ and for temperatures between $900{ }^{\circ} \mathrm{C}$ and $1100{ }^{\circ} \mathrm{C}$. According to our previous results for the composition of wüstite under circumstellar conditions a defect concentration of $\delta=0.01$ is representative for that of wüstite in the hydrogen rich environment of a circumstellar dust shell (cf. Fig. 2). We extrapolated the results of Rickert \& Weppner (1974) to $\delta=0.01$ which yields the following temperature dependent cation diffusion coefficient

$D=4 \times 10^{2} \mathrm{e}^{-24900 / T}$.

Because of very similar ionic radii of $\mathrm{Mg}^{2+}$ and $\mathrm{Fe}^{2+}$ and lattice constants of $\mathrm{MgO}$ and $\mathrm{FeO}$ (Lide 1995) we apply this cation diffusion coefficient also to magnesiowüstite.

The characteristic timescale for diffusion across a dust grain of size $a$ is

$t_{\text {diff }}=\frac{a^{2}}{D}$

This is the characteristic timescale for the homogenization of composition differences within a grain of size $a$. In Fig. 3 this timescale is plotted as a function of temperature for grain sizes of $a=0.1$ and $0.01 \mu \mathrm{m}$.

We compare this with the characteristic cooling timescale

$t_{\mathrm{cool}}=\frac{r}{v_{\exp }}$

in the outflowing gas, where $r$ is the radial distance and $v_{\text {exp }}$ the expansion velocity. If we assume for simplicity a grey temperature structure

$T(r)=\frac{T_{\mathrm{eff}}}{\sqrt{2}} \sqrt{\frac{R_{*}}{r}}$

this determines $\tau_{\text {cool }}$ as function of temperature $T$. For a star with $T_{\text {eff }}=2500 \mathrm{~K}, L_{*}=10^{4} L_{\odot}$, and an expansion velocity of $v_{\exp }=10 \mathrm{~km} \mathrm{~s}^{-1}$ the resulting cooling timescale is plotted in Fig. 3.

An inspection of this figure shows that the homogenization timescale for particles of $0.1 \mu \mathrm{m}$ size is less than the cooling timescale for $T \gtrsim 550 \mathrm{~K}$. Since usually grain growth is already suppressed at such low temperatures because of rapid dilution of the gas by highly supersonic expansion of the stellar wind material, we conclude that cation diffusion in magnesiowüstite is rapid enough that significant chemical composition gradients cannot by maintained within a magnesiowüstite grain of size $a \lesssim 0.1 \mu \mathrm{m}$. The magnesiowüstite grains have an internally homogeneous chemical composition which, however, may change with radial distance $r$ from the star. 


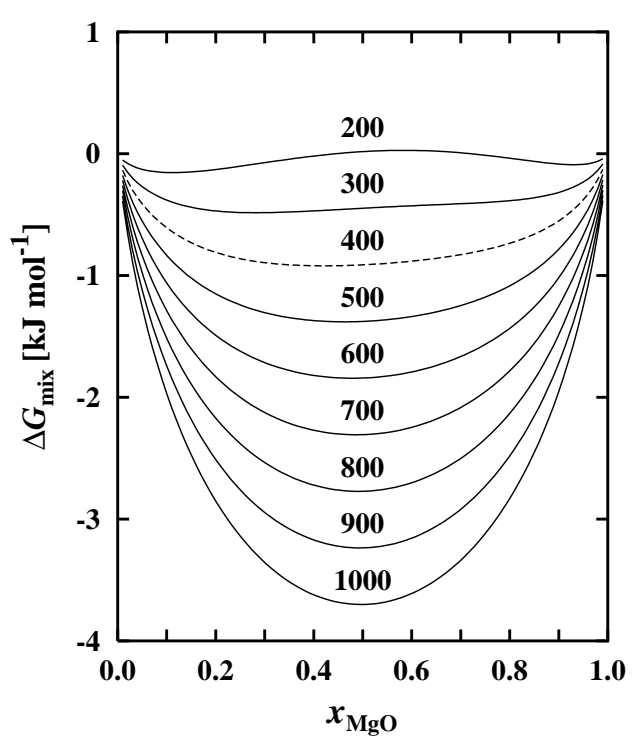

Fig. 4. Variation of the free enthalpy of mixing $\Delta G_{\text {mix }}(x, T)$ of $\mathrm{FeO}$ and $\mathrm{MgO}$ with mole fraction $x_{\mathrm{MgO}}$ in the solid solution for the indicated temperatures. At $T \lesssim 400 \mathrm{~K}$ (dashed line) the mixing enthalpy $\Delta G_{\text {mix }}(x, T)$ starts to be parabolic upwards in the middle region. For such temperatures magnesiowüstite is unstable against unmixing in two phases with different compositions.

\subsection{Spinodal decomposition of magnesiowüstite}

Magnesiowüstite is a non-ideal solid solution of wüstite $\left(\mathrm{Fe}_{1-\delta}\right)$ and periclase $(\mathrm{MgO})$. For simplicity we neglect the $\mathrm{Fe}_{2} \mathrm{O}_{3}$ component for the moment and consider only the mixture of $\mathrm{FeO}$ and $\mathrm{MgO}$.

Non-ideal solid solutions may unmix below some critical temperature $T_{\mathrm{c}}$ into two phases with different compositions. This unmixing requires that the graph of the free enthalpy of mixing

$$
\begin{aligned}
\Delta G_{\text {mix }}= & R T\left(x_{\mathrm{MgO}} \ln x_{\mathrm{MgO}}+x_{\mathrm{FeO}} \ln x_{\mathrm{FeO}}\right. \\
& \left.+x_{\mathrm{MgO}} \ln \gamma_{\mathrm{MgO}}+x_{\mathrm{FeO}} \ln \gamma_{\mathrm{FeO}}\right)
\end{aligned}
$$

becomes for some interval of mixing ratios $x_{\mathrm{MgO}}$ concave from below in order that the unmixing in two phases with different composition lowers the free enthalpy (cf. Philpotts 1990). In Fig. 4 we have plotted the free enthalpy of mixing (40) of $\mathrm{MgO}$ and $\mathrm{FeO}$ (neglecting $\mathrm{Fe}_{2} \mathrm{O}_{3}$ ) as a function of mole fraction $x_{\mathrm{MgO}}$ and temperature $T$. As the figure shows, these curves start to develop a concave part at about $T=400 \mathrm{~K}$ (dashed curve). Below this temperature magnesiowüstite becomes unstable against unmixing (spinodal decomposition).

The unmixing requires, however, that cations migrate within the lattice over some distance in order to separate into two components with different compositions. Usually at the onset of exsolution there form exsolution lamellae on scales of the order of $0.01 \mu \mathrm{m}$ (e.g. Putnis 1995). Figure 3 shows that cooling in the stellar wind is too rapid that unmixing even on spatial scales of the order of $0.01 \mu \mathrm{m}$ is possible at temperatures where magnesiowüstite becomes unstable against unmixing. Spinodal decomposition is kinetically forbidden under stellar wind conditions.

\section{Non-equilibrium formation of magnesiowüstite}

In this section we consider the growth of magnesiowüstite grains under non-equilibrium conditions in a stellar outflow. For simplicity we neglect the small fraction of $\mathrm{Fe}_{2} \mathrm{O}_{3}$ in the solid solution and consider grains with composition $\mathrm{Mg}_{x} \mathrm{Fe}_{1-x} \mathrm{O}$, but one should bear in mind that in real grains a fraction of $\lesssim 1 \%$ of the $\mathrm{Fe}^{2+}$ cations is replaced by $\mathrm{Fe}^{3+}$ cations.

\subsection{Grain growth}

The raw material from which magnesiowüstite is formed in matter with standard cosmic element abundance and temperature and pressure conditions encountered in stellar outflows $\left(T<1000 \mathrm{~K}, P \approx 10^{-10}\right.$ bar) are free $\mathrm{Mg}$ and $\mathrm{Fe}$ atoms and $\mathrm{H}_{2} \mathrm{O}$ molecules from the gas phase. Since the abundance of $\mathrm{H}_{2} \mathrm{O}$ in the gas phase is very much higher than that of $\mathrm{Mg}$ and Fe we assume that the growth of $\mathrm{Mg}_{x} \mathrm{Fe}_{1-x} \mathrm{O}$ is determined by the addition of $\mathrm{Mg}$ and $\mathrm{Fe}$ and that the rate of addition of $\mathrm{O}$ to the growing particle by reaction with $\mathrm{H}_{2} \mathrm{O}$ molecules always adjusts to the rates of $\mathrm{Mg}$ and $\mathrm{Fe}$ addition.

If $J^{\mathrm{gr}}$ denotes the growth rate per unit time and surface area we have

$J_{\mathrm{Mg}}^{\mathrm{gr}}=\alpha_{\mathrm{Mg}} v_{\mathrm{th}, \mathrm{Mg}} n_{\mathrm{Mg}}$

$J_{\mathrm{Fe}}^{\mathrm{gr}}=\alpha_{\mathrm{Fe}} v_{\mathrm{th}, \mathrm{Fe}} n_{\mathrm{Fe}}$

where $n$ denotes the particle density,

$v_{\text {th }}=\sqrt{\frac{2 k T}{\pi m}}$

the average thermal velocity of the particles ( $m=$ particle mass), and $\alpha$ the growth (sticking) coefficient.

The vapour of magnesiowüstite contains $\mathrm{Fe}$ and $\mathrm{Mg}$ only as free atoms. The abundance of $\mathrm{FeO}$ and $\mathrm{MgO}$ molecules in the vapour is negligible. The injection rates $J^{\text {vap }}$ per unit time and surface area of $\mathrm{Mg}$ and $\mathrm{Fe}$ into the gas phase by vaporization of magnesiowüstite then are

$J_{\mathrm{Mg}}^{\mathrm{vap}}=\alpha_{\mathrm{Mg}} v_{\mathrm{th}, \mathrm{Mg}} \frac{p_{v, \mathrm{Mg}}}{k T}$

$J_{\mathrm{Fe}}^{\mathrm{vap}}=\alpha_{\mathrm{Fe}} v_{\mathrm{th}, \mathrm{Fe}} \frac{p_{v, \mathrm{Fe}}}{k T}$,

where $p_{v}$ is the partial pressure of $\mathrm{Mg}$ or $\mathrm{Fe}$ in the vapour of $\mathrm{Mg}_{x} \mathrm{Fe}_{1-x} \mathrm{O}$ in a chemical equilibrium state.

Let $N_{\mathrm{Mg}}$ and $N_{\mathrm{Fe}}$ denote the total numbers of $\mathrm{Mg}$ and $\mathrm{Fe}$ cations, respectively, contained in a grain. The total number of oxygen anions, which equals the total number of unit cells of the cubic lattice of magnesiowüstite contained in a grain, is

$N_{\mathrm{c}}=N_{\mathrm{Mg}}+N_{\mathrm{Fe}}$.

The volume of the grain is

$V_{\mathrm{gr}}=N_{\mathrm{c}} a_{0}^{3}$

where $a_{0}$ is the lattice constant of magnesiowüstite and the surface area of the grain is

$A_{\mathrm{gr}}=6 N_{\mathrm{c}}^{\frac{2}{3}} a_{0}^{2}$. 
The cubic shape of submicron sized $\mathrm{MgO}$ grains can nicely be seen in Fig. 4 in Rietmeijer et al. (1999a) and Fig. 2 in Rietmeijer et al. (2002).

The growth of magnesiowüstite grains according to our assumptions is described by the equations

$\frac{\mathrm{d} N_{\mathrm{Mg}}}{\mathrm{d} t}=A_{\mathrm{gr}}\left(J_{\mathrm{Mg}}^{\mathrm{gr}}-J_{\mathrm{Mg}}^{\mathrm{vap}}\right)$
$\frac{\mathrm{d} N_{\mathrm{Fe}}}{\mathrm{d} t}=A_{\mathrm{gr}}\left(J_{\mathrm{Fe}}^{\mathrm{gr}}-J_{\mathrm{Fe}}^{\mathrm{vap}}\right)$.

By adding these two equations we obtain an equation for the sidelength

$a_{\mathrm{gr}}=N_{\mathrm{c}}^{\frac{1}{3}} a_{0}$

of the magnesiowüstite cubes

$\frac{\mathrm{d} a_{\mathrm{gr}}}{\mathrm{d} t}=2 a_{0}^{3}\left(J_{\mathrm{Mg}}^{\mathrm{gr}}-J_{\mathrm{Mg}}^{\mathrm{vap}}+J_{\mathrm{Fe}}^{\mathrm{gr}}-J_{\mathrm{Fe}}^{\mathrm{vap}}\right)$.

For the mole fraction

$x_{\mathrm{FeO}}=\frac{N_{\mathrm{Fe}}}{N_{\mathrm{Mg}}+N_{\mathrm{Fe}}}$

of $\mathrm{FeO}$ in the grains we obtain the equation

$\frac{\mathrm{d} x_{\mathrm{FeO}}}{\mathrm{d} t}=\frac{6 a_{0}^{3}}{a_{\mathrm{gr}}}\left[\left(1-x_{\mathrm{FeO}}\right)\left(J_{\mathrm{Fe}}^{\mathrm{gr}}-J_{\mathrm{Fe}}^{\mathrm{vap}}\right)-x_{\mathrm{FeO}}\left(J_{\mathrm{Mg}}^{\mathrm{gr}}-J_{\mathrm{Mg}}^{\mathrm{vap}}\right)\right]$

The system of Eqs. (52) and (54) describes the variation of size and composition of the magnesiowüstite grains under nonequilibrium compositions.

The consumption of $\mathrm{H}_{2} \mathrm{O}, \mathrm{Fe}$, and $\mathrm{Mg}$ from the gas phase by formation of magnesiowüstite has to be considered analogous to Eqs. (51), (53), (54) of Ferrarotti \& Gail (2001).

\subsection{Calculation of vapour pressures}

For solving Eqs. (52) and (54) we need to know the vapour pressures $p_{v, \mathrm{Mg}}$ and $p_{v, \mathrm{Fe}}$ in (44) and (45). These are calculated for the hydrogen rich environment of a stellar outflow as described in Sect. 2.2.1, but with the simplification that the component $\mathrm{Fe}_{2} \mathrm{O}_{3}$ in the solid solution is neglected:

$p_{v, \mathrm{Mg}}=x_{\mathrm{MgO}} \gamma_{\mathrm{MgO}} p_{v, \mathrm{Mg}}^{*}$

$p_{v, \mathrm{Fe}}=x_{\mathrm{FeO}} \gamma_{\mathrm{FeO}} p_{v, \mathrm{Fe}}^{*}$,

where

$p_{v, \mathrm{Mg}}^{*}=\frac{p_{\mathrm{H}_{2}}}{p_{\mathrm{H}_{2} \mathrm{O}}} \mathrm{e}^{-\Delta G_{2} / R T}$

$p_{v, \mathrm{Fe}}^{*}=\frac{p_{\mathrm{H}_{2}}}{p_{\mathrm{H}_{2} \mathrm{O}}} \mathrm{e}^{-\Delta G_{1} / R T}$

are the vapour pressures of the pure components $\mathrm{MgO}(\mathrm{s})$ and $\mathrm{FeO}(\mathrm{s})$ in chemical equilibrium with the gas phase.

\subsection{Relation between sticking coefficients}

The relation between the vaporization rates for $\mathrm{Mg}$ and $\mathrm{Fe}$ atoms from the surface of a magnesiowüstite grain of composition $\mathrm{Mg}_{x} \mathrm{Fe}_{1-x}$ is not known. If vaporization does not change the composition of magnesiowüstite one has

$\alpha_{\mathrm{Fe}}=\alpha_{\mathrm{Mg}} \frac{v_{\mathrm{th}, \mathrm{Mg}}}{v_{\mathrm{th}, \mathrm{Fe}}}$.

We assume this to be valid as long as experimental values are not available.

The sticking coefficient for pure $\mathrm{MgO}$ has been experimentally determined from vaporization experiments by Hashimoto (1990). A value of about $\alpha=0.2$ was determined which will be used in our model calculations also for the $\mathrm{MgO}$ component of magnesiowüstite. The coefficient $\alpha_{\mathrm{Fe}}$ is determined from (59).

\subsection{Growth centres}

The calculations are performed under the simplifying assumption that the magnesiowüstite grows onto some already existing seed nuclei. The possible nucleation of such grains directly from the gas phase will be studied as outlined in Köhler et al. (1997) in a separate paper.

For the seed nuclei we assume a size of $1 \mathrm{~nm}$ as in our previous papers in this series, but we increased in our model calculation the number density from $1 \times 10^{-13}$ to $3 \times 10^{-13}$ seed nuclei per hydrogen nucleus. The reason was that the lower number of seed nuclei seems to give too small overall degrees of condensation for the silicates and probably too big silicate dust particle radii which are bigger than the upper cutoff of the size distribution derived by Jura (1996). With our new choice for the seed number density the results of the model calculation are in better agreement with Jura results.

\section{Magnesiowüstite in circumstellar shells}

\subsection{Wind model}

Some explorative calculations have been performed to check whether magnesiowüstite may be formed in stellar outflows around late type stars. The calculations are based on the simplified wind model already used in the first three papers of this series (Gail \& Sedlmayr 1999; Ferrarotti \& Gail 2001, 2002): A stationary, spherically symmetrically wind is flowing out of the stellar atmosphere from a star with

$L_{*}=2 \times 10^{4} L_{\odot}, \quad M_{*}=1 M_{\odot}, \quad T_{\text {eff }}=3000 \mathrm{~K}$.

It enters the dust formation zone with an assumed velocity of $1 \mathrm{~km} \mathrm{~s}^{-1}$ and is accelerated to supersonic velocity by radiation pressure on dust grains once dust formation commences. Details of the calculation of the wind models are described in the previous papers.

\subsection{Dust model}

The models are calculated for an oxygen rich element mixture with abundances according to Anders \& Grevesse (1989) and 

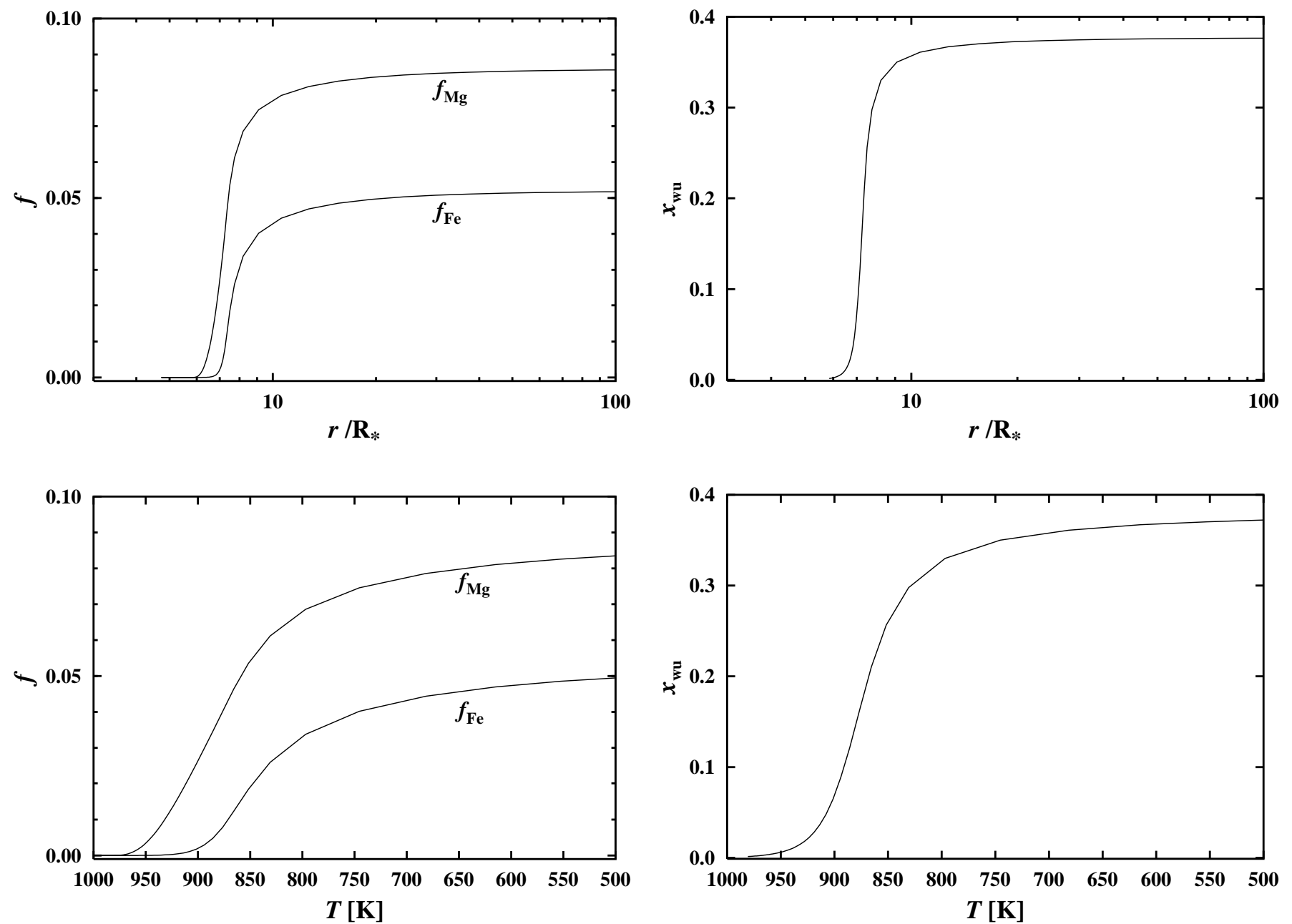

Fig. 5. Degree of condensation of $\mathrm{Mg}$ and $\mathrm{Fe}$ into magnesiowüstite as function of radial distance (upper pictures) and of temperature of the wind material (lower pictures). Pictures a) and c) show the fractions $f_{\mathrm{Mg}}$ and $f_{\mathrm{Fe}}$ of the $\mathrm{Mg}$ and Fe, respectively, condensed into magnesiowüstite. Pictures b) and d) show the mole fraction $x_{\mathrm{FeO}}$ of $\mathrm{FeO}$ in magnesiowüstite. The results are for a wind model with a mass-loss rate of $\dot{M}=$ $3 \times 10^{-6} M_{\odot} \mathrm{yr}^{-1}$.

Grevesse \& Noels (1993). The dust components considered in our previous non-equilibrium condensation calculations were olivine $\left(\mathrm{Mg}_{2 x} \mathrm{Fe}_{2(1-x)} \mathrm{SiO}_{4}\right)$, pyroxene $\left(\mathrm{Mg}_{x} \mathrm{Fe}_{1-x} \mathrm{SiO}_{3}\right)$, iron $(\mathrm{Fe})$, quartz $\left(\mathrm{SiO}_{2}\right)$, and periclase $(\mathrm{MgO})$ (Gail \& Sedlmayr 1999; Ferrarotti \& Gail 2001, 2002). Details of how the nonequilibrium condensation of these dust components is calculated are described in the previous papers and are not repeated at this place.

The condensation calculation for $\mathrm{MgO}$ here is extended to the calculation of magnesiowüstite condensation, i.e. Eqs. (52) and (54) are solved simultaneously with the equations for the other dust components and the stellar wind.

\subsection{Results for condensation of magnesiowüstite}

Figure 5 shows in the left two pictures the radial variation of the degrees of condensation $f_{\mathrm{Mg}}$ and $f_{\mathrm{Fe}}$ of $\mathrm{Mg}$ and $\mathrm{Fe}$, respectively, into solid magnesiowüstite, and in the right two pictures the mole fraction of $\mathrm{FeO}$ in the magnesiowüstite. A wind model with a mass loss rate of $\dot{M}=3 \times 10^{-6} M_{\odot} \mathrm{yr}^{-1}$ is assumed.
Figure 5a shows the increase of the degree of condensation of $\mathrm{Mg}$ and $\mathrm{Fe}$ into magnesiowüstite as a parcel of gas moves outwards. Initially nearly pure periclase $(\mathrm{MgO})$ forms with an only negligible fraction of the $\mathrm{Fe}$ bearing end member $\mathrm{FeO}$ in the solid solution. The incorporation of FeO into the solid solution starts with a considerable delay, until the gas parcel has moved to lower temperature. Figure 5c, again, shows the degree of condensation of $\mathrm{Mg}$ and $\mathrm{Fe}$ into magnesiowüstite, but now as function of temperature. Comparison with Fig. 1 shows that massive incorporation of $\mathrm{FeO}$ into $\mathrm{Fe}_{x} \mathrm{Mg}_{1-x} \mathrm{O}$ starts at about $850 \mathrm{~K}$ which is roughly the temperature where the stability limit for condensation of pure $\mathrm{FeO}$ is crossed from above (cf. also the left part of Fig. 2). Above this temperature the Fe content of the solid solution is only small, below a solid solution with an Fe content of nearly $40 \%$ does form, as can be seen from Figs. $5 b$ or d. The Fe content remains less than $50 \%$ despite a much higher partial pressure of $\mathrm{Fe}$ than of $\mathrm{Mg}$ atoms in the gas phase because prior to the onset of $\mathrm{FeO}$ condensation already significant amounts of $\mathrm{Mg}$ condensed as nearly pure $\mathrm{MgO}$. 

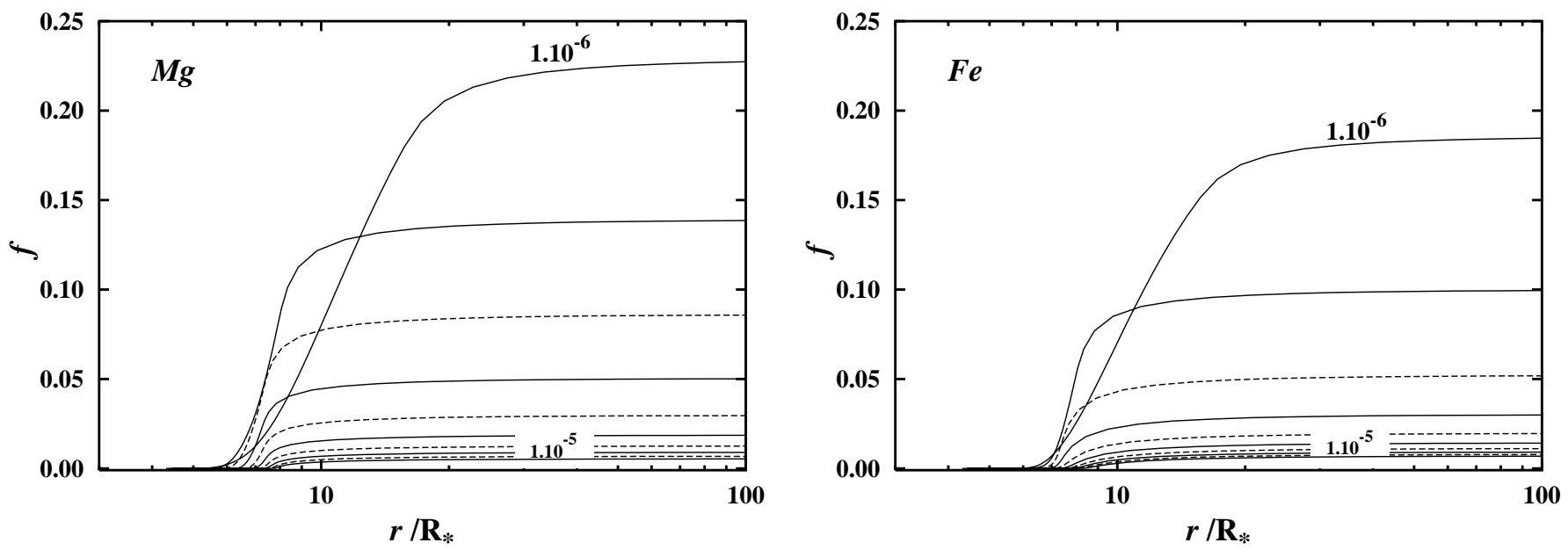

Fig. 6. Degree of condensation of $\mathrm{Mg}$ and Fe into magnesiowüstite as function of radial distance for different mass loss rates between $\dot{M}=$ $1 \times 10^{-6} M_{\odot} \mathrm{yr}^{-1}$ and $\dot{M}=1 \times 10^{-5} M_{\odot} \mathrm{yr}^{-1}$ in steps of $10^{-6} M_{\odot} \mathrm{yr}^{-1}$.

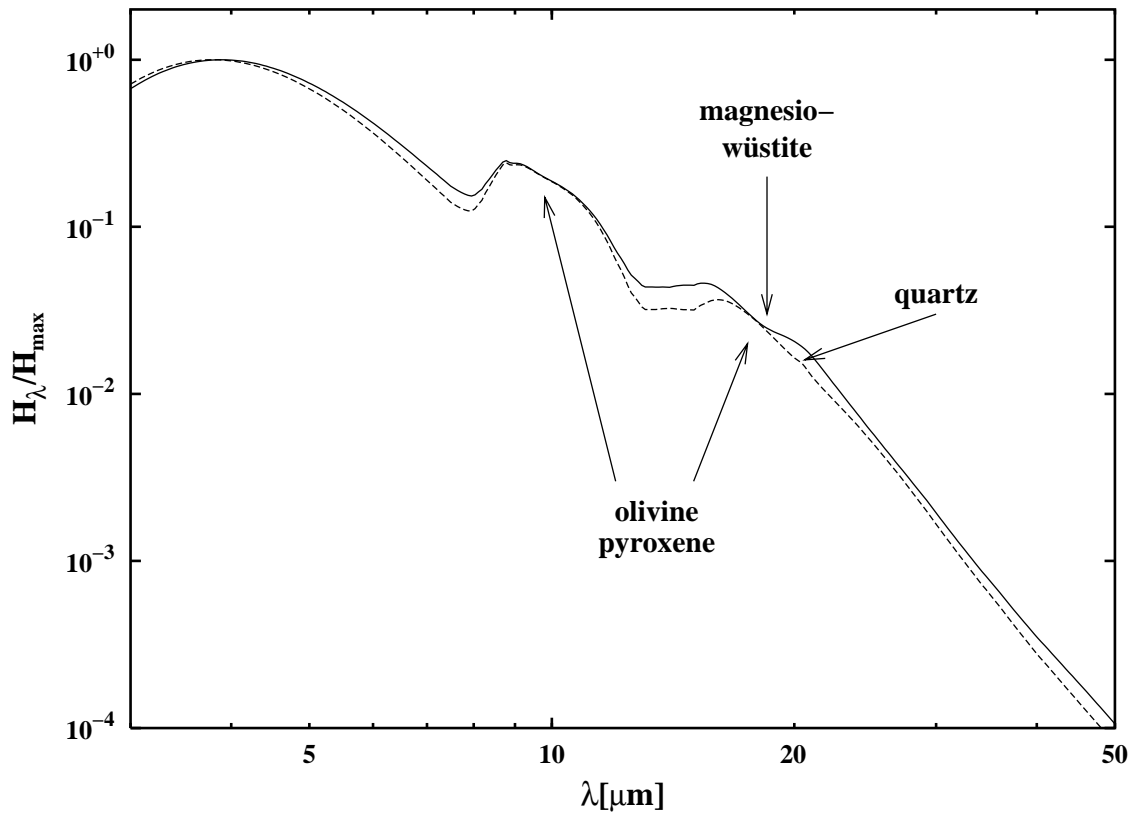

Fig. 7. Spectrum from a circumstellar dust shell for a wind model with $\dot{M}=1 \times 10^{-6} M_{\odot} \mathrm{yr}^{-1}$. Full line including magnesiowüstite as absorber, dashed line omitting magnesiowüstite as absorber.
Figure 6 shows the radial variation of the degree of condensation of $\mathrm{Mg}$ and $\mathrm{Fe}$ into magnesiowüstite for different mass loss rates. The quantities of magnesiowüstite formed in the outflow decrease with increasing mass-loss rate. The reason for this is that olivine is the first abundant condensate in the wind, which starts to condense at a significantly higher temperature than magnesiowüstite (cf. Fig. 1). The higher the mass-loss rate is, the earlier sufficient amounts of silicate dust have condensed for driving the wind to highly supersonic outflow velocities. Dust components which start to condense not before significant acceleration has taken place are serious hindered in their condensation by rapid dilution of the outflowing gas. For mass-loss rates $\dot{M} \lesssim 4 \times 10^{-6} M_{\odot} \mathrm{yr}^{-1}$ magnesiowüstite starts to condense before strong acceleration of the wind material by radiation pressure on silicates has taken place, for $\dot{M} \gtrsim 4 \times 10^{-6} M_{\odot} \mathrm{yr}^{-1}$ condensation of magnesiowüstite is essentially suppressed because the outflow velocity is already much too high.
The quantities of magnesiowüstite formed at mass-loss rates $\dot{M} \lesssim 4 \times 10^{-6} M_{\odot} \mathrm{yr}^{-1}$ are not very high, only of the order of up to twenty percent of the totally available condensible material, but the quantities are not negligibly small and should contribute to the opacity of the circumstellar dust material. Since many of the oxygen rich stars have mass loss rates $\dot{M} \lesssim 4 \times 10^{-6} M_{\odot} \mathrm{yr}^{-1}$ (cf. Habing 1996; Loup et al. 1993) or even as small as a few times $10^{-7} M_{\odot} \mathrm{yr}^{-1}$ (Olofsson et al. 2002) magnesiowüstite probably is a wide spread circumstellar dust material in objects with mass-loss rates below about $2 \times 10^{-6} M_{\odot} \mathrm{yr}^{-1}$.

\subsection{Calculation of IR-spectra from the dust shell}

As a test case the emitted infrared spectrum from a circumstellar dust shell for a wind model with $\dot{M}=1 \times 10^{-6} M_{\odot} \mathrm{yr}^{-1}$ is calculated. The temperature-density structure and the 
radial variation of the degrees of condensation of the different dust species (amorphous olivine and pyroxene, metallic iron, quartz, and magnesiowüstite) was taken from the wind model. Radiative transfer in the spherically symmetric dust shell is calculated by the $p-z$-method, solving the transfer equation along rays with the Feautrier method. The extinction of magnesiowüstite grains was calculated for small cubic grains with side lengths of the cubes as determined from the solution of Eqs. (52) and (54), since the condensation experiments of Rietmeijer et al. (1999a, 2002) clearly show that even on the nm-scale magnesiowüstite grains have cubic shapes, though other dust materials on such small scales often form roundish grains which may be approximated by ellipsoids or spheres. For the optical constants of magnesiowüstite the data set for the composition $\mathrm{Mg}_{0.6} \mathrm{Fe}_{0.4} \mathrm{O}$ from Henning et al. (1995) is used since this is closest to the composition found in our model calculation (cf. Fig. 5).

Figure 7 shows the calculated emission spectrum with (full line) and without (dashed line) considering magnesiowüstite as an absorber. Since magnesiowüstite is only a minor dust component, as Fig. 6 shows, the differences in the emitted flux are small, but non-negligible. In the region of the resonance around $\lambda \approx 19 \mu \mathrm{m}$, cf. Fig. A.1, there is a small dip in the flux due to magnesiowüstite, sitting on the shoulder of the broad $18 \mu \mathrm{m}$ emission band due to amorphous silicates. The feature is hardly visible in model spectra for wind models with $\dot{M} \gtrsim 2 \times 10^{-6} M_{\odot} \mathrm{yr}^{-1}$, but becomes significant for $\dot{M} \leq 1 \times 10^{-6} M_{\odot} \mathrm{yr}^{-1}$. Probably for $\dot{M} \leq 1 \times 10^{-6} M_{\odot} \mathrm{yr}^{-1}$ the magnesiowüstite feature becomes a prominent emission feature $^{1}$, but unfortunately our model program cannot calculate self consistent wind models with $\dot{M}<1 \times 10^{-6} M_{\odot} \mathrm{yr}^{-1}$ since it is assumed that the supersonic outflow is driven by dust condensation, which is impossible if mass loss rates become very low (Gail \& Sedlmayr 1987).

Molster (2000) and Molster et al. (2002b) found a dust feature present in some circumstellar dust shells which peaks just below $19 \mu \mathrm{m}$, which could not clearly be related to the abundant silicate dust species. Posch et al. (2002) find a feature at about $19.5 \mu \mathrm{m}$ in the ISO spectra of a number of objects with rather low mass-loss rates and propose its carrier to be magnesiowüstite. This feature at $\approx 19 \mu \mathrm{m}$ is located at essentially the same wavelength as that found in the present model calculation. The somewhat lower wavelength of the feature in our model as compared to the feature observed by Posch et al. (2002) certainly is due to the different iron content found in our model calculation. The calculated mole fraction of $\mathrm{FeO}$ in magnesiowüstite depends on the vaporization coefficients $\alpha$ for $\mathrm{FeO}$ and $\mathrm{MgO}$ which are not known with sufficient accuracy.

In our calculation the feature seems to be somewhat weaker than the observed feature but this may result from our special choice of model parameters for the wind (Sect. 4.1) or from the special choice for the density of seed nuclei (Sect. 3.4). The coincidence between the calculated magnesiowüstite feature and the feature observed in the spectra of some circumstellar dust

\footnotetext{
1 This has been found, if models were calculated for $\dot{M} \leq 1 \times$ $10^{-6} M_{\odot} \mathrm{yr}^{-1}$ with a fixed expansion velocity and without iterating for self-consistency.
}

Table 1. Coefficients $C_{m}, n_{m}$ for the normal modes of cubic grains according to Fuchs (1975).

\begin{tabular}{ccccccc}
\hline \hline$m$ & 1 & 2 & 3 & 4 & 5 & 6 \\
\hline$C_{m}$ & 0.44 & 0.24 & 0.04 & 0.05 & 0.10 & 0.09 \\
$n_{m}$ & 0.214 & 0.297 & 0.345 & 0.440 & 0.563 & 0.706 \\
\hline
\end{tabular}

shells may indicate that magnesiowüstite really is one of the components of the multicomponent dust mixture formed in the outflow from oxygen rich late type stars with low mass loss rate.

\section{Concluding remarks}

We have considered in some detail the possibility of formation of oxidic dust particles with composition $\mathrm{Mg}_{1-x} \mathrm{Fe}_{x} \mathrm{O}$ in oxygen rich circumstellar dust shells. In the past it has frequently been speculated that iron oxide grains may exist and possibly may be detectable by solid state absorption bands in the far infrared spectral region. Here we have shown that sufficient laboratory data for magnesiowüstite are available to calculate its condensation under non-equilibrium conditions with the result, that it probably is formed in sufficient quantities to be detectable as a minor dust component. The calculated position of the resonance of magnesiowüstite corresponds to a not yet identified dust feature seen in some oxygen rich circumstellar dust shells, which might indicate that magnesiowüstite really exists in such shells. Clearly, more detailed model calculations are required for a definite identification of this dust species.

Acknowledgements. This work has been performed as part of a project of the special research programme SFB 439 "Galaxies in the Young Universe" which is supported by the Deutsche Forschungsgemeinschaft (DFG). We thank an unknown referee whose comments have much improved the paper.

\section{Appendix A: Extinction by small cubes}

The extinction by small cubes has been calculated by Fuchs (1975). The dielectric polarizability of a cube with volume $V$ is $\alpha=V \sum_{m} \frac{C_{m}}{n_{m}} \frac{\epsilon-1}{\epsilon-1+n_{m}^{-1}}$

where $\epsilon$ is the complex dielectric constant of bulk matter. A factor of $4 \pi$ has been introduced in Eq. (1) of Fuchs in order to agree with the definition of $\alpha$ as in Bohren \& Huffman (1983). The constants $C_{m}$ and $n_{m}$ are given in Table 1 . The absorption and scattering cross sections of small cubic dust grains then are (Bohren \& Huffman 1983)

$$
\begin{aligned}
\sigma_{\lambda}^{\mathrm{abs}} & =\frac{2 \pi}{\lambda} \mathfrak{J} m \alpha \\
\sigma_{\lambda}^{\text {sca }} & =\frac{128 \pi^{3}}{3 \lambda^{4}}|\alpha|^{2} .
\end{aligned}
$$

Figure A. 1 shows the absorption cross section in the region of the strong resonance around $\approx 19 \mu \mathrm{m}$ of magnesiowüstite with composition $\mathrm{Mg}_{0.6} \mathrm{Fe}_{0.4} \mathrm{O}$, calculated with optical data from Henning et al. (1995). Note that for cubes the peak of the resonance is shifted to longer wavelength. 


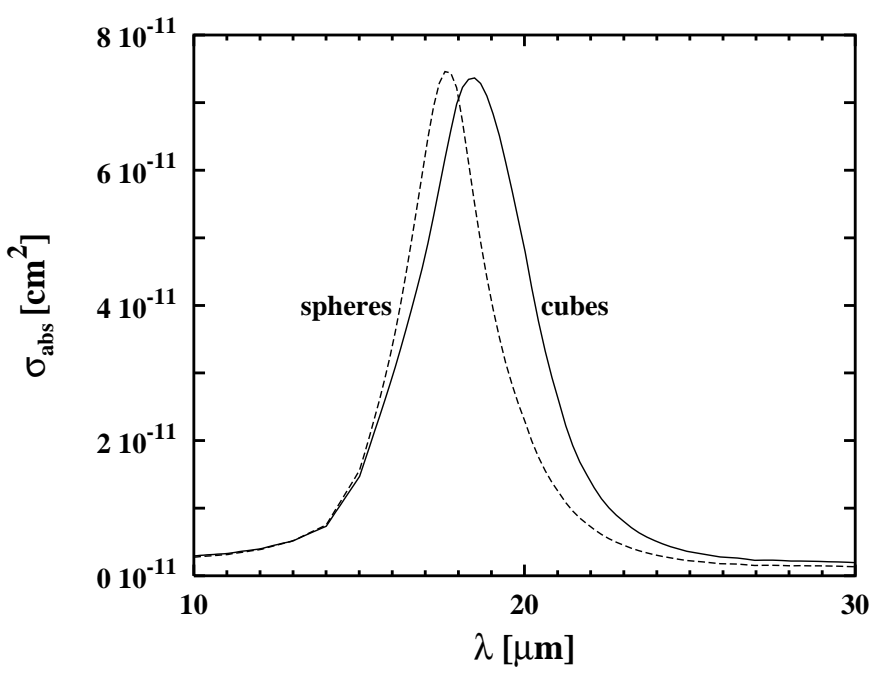

Fig. A.1. Absorption cross section of $\mathrm{Mg}_{0.6} \mathrm{Fe}_{0.4} \mathrm{O}$ for small spheres with $a=0.1 \mu \mathrm{m}$ and for cubes of equal volume.

\section{References}

Aitken, D. K., Smith, C. H., James, S. D., Roche, P. F., \& Hough, J. H. 1988, MNRAS, 230, 629

Anders, E., \& Grevesse, N. 1989, Geochim. et Cosmochim. Acta, 53, 197

Atkins, P. W. 1994, Physical Chemistry, 5th ed. (Oxford University Press)

Barin, I. 1992, Thermodynamical Data of Pure Substances (Verlag Chemie, Weinheim)

Bohren, C. F., \& Huffman, D. R. 1983, Absorption and Scattering of Light by Small Particles (Wiley \& Sons, New York)

Ferrarotti, A. S., \& Gail, H.-P. 2001, A\&A, 371, 133

Ferrarotti, A. S., \& Gail, H.-P. 2002, A\&A, 382, 256

Fuchs, R. 1975, Phys. Rev. B, 11, 1732

Gail, H.-P. 1998, A\&A, 332, 1099

Gail, H.-P., \& Sedlmayr, E. 1987, A\&A, 177, 186

Gail, H.-P., \& Sedlmayr, E. 1999, A\&A, 347, 594

Grevesse, N., \& Noels, A. 1993, in Origin and Evolution of the Elements, ed. N. Prantzos, E. Vangioni-Flam, \& M. Cassé (Cambridge University Press, Cambridge), 15
Grossman, L. 1972, Geochim. et Cosmochim. Acta, 36, 597

Habing, H. J. 1996, A\&A Rev., 7, 97

Hashimoto, A. 1990, Nature, 347, 53

Henning, Th., Begemann, B., Mutschke, H., \& Dorschner, J. 1995, A\&AS, 112, 143

Jura, M. 1996, ApJ, 472, 806

Köhler, T. M., Gail, H.-P., \& Sedlmayr, E. 1997, A\&A, 320, 553

Lide, R. D. 1995, CRC Handbook of Chemistry and Physics, 76th ed. (CRC Press, Boca Raton etc.)

Loup, C., Forveille, T., Omont, A., \& Paul, J. F. 1993, A\&AS, 99, 291

Molster, F. J., Waters, L. B. F. M., Trams, N. R., et al. 1999, A\&A, 350,163

Molster F. J. 2000, Thesis, University of Amsterdam

Molster, F. J., Waters, L. B. F. M., Tielens, A. G. G. M., \& Barlow, M. J. 2002a, A\&A, 382, 184

Molster, F. J., Waters, L. B. F. M., \& Tielens, A. G. G. M. 2002b, A\&A, 382, 222

Molster, F. J., Waters, L. B. F. M., Tielens, A. G. G. M., Koike, C., \& Chihara, H. 2002c, A\&A, 382, 241

Olofsson, H., Gonzàlez Delgado, D., Kerschbaum, F., \& Schöier, F. L. 2002, A\&A, 391, 1053

Onaka, T., de Jong, T., \& Willems, F. J. 1989, A\&A, 218, 169

Philpotts, A. R. 1990, Principles of igneous and metamorphic petrology (Prentice Hall, Englewood Cliffs)

Posch, T., Kerschbaum, F., Mutschke, H., Dorschner, J., \& Jäger, C. 2002, A\&A, 393, L7

Putnis, A. 1995, Introduction to mineral science (Cambridge University Press, Cambridge)

Rickert, H., \& Weppner, W. 1974, Z. Naturforsch., 29a, 1849

Rietmeijer, F. J. M. 1992, ApJL, 400, L39

Rietmeijer, F. J. M., Nuth III, J. A., \& Karner, J. M. 1999a, ApJ, 527, 395

Rietmeijer, F. J. M., Nuth III, J. A., \& Karner, J. M. 1999b, Phys. Chem. Chem. Phys., 1, 1511

Rietmeijer, F. J. M., Hallenbeck, S. L., Nuth III, J. A., \& Karner, J. M. 2002, Icarus, 156, 269

Sharp, C. M., \& Huebner, W. F. 1990, ApJS, 72, 417

Srečec, I., Ender, A., Woerman, E., et al. 1987, Phys. Chem. Minerals, 14,492

Waters, L. B. F. M., Molster, F. J., de Jong, T., et al. 1996, A\&A, 315, L361 